\title{
Los «tristanes» en verso como educación sentimental*
}

\author{
ISABEL DE RIQUER \\ Universitat de Barcelona \\ riquer@ub.edu
}

\begin{abstract}
Resumen: La leyenda tristaniana circuló por los centros cortesanos europeos durante la Edad Media y episodios de sus versiones en verso fueron imitados en varias novelas. Sin embargo, al mismo tiempo que la historia era objeto de severas críticas por parte de los moralistas, poetas y novelistas se dividieron en pro y anti tristanianos. Para unos la pareja de enamorados era un ejemplo de amor hasta la muerte, mientras que otros criticaban la relación adúltera provocada por la bebida de un filtro y no por la unión de sus corazones. Dante llevó a Tristán al Infierno, encabezando un grupo de más de mil caballeros y damas que habían muerto a causa de sus relaciones adúlteras. Y mientras las críticas fueron entonces dirigidas hacia los lectores de la novela, las familias nobles de Europa adornaban sus mansiones con tapices, frescos y objetos en que estaban reproducidas las escenas más conocidas y significativas de la leyenda tristaniana.
\end{abstract}

Palabras clave: Tristán e Iseo. Versiones francesas en verso. Recepción durante la Edad Media. Elogios, imitaciones y críticas. «Galería de enamorados». Lectores del siglo XXI.

The legend of Tristan and Iseut as a Sentimental Education

\begin{abstract}
The legend of Tristan obsessed educated Europe during the Middle Ages, and their story was the most praised and imitated of all romances. At the same time, owever, ir received more criticism and caused more scandal than any other. Beginning with the authors of the Old French poems of the twelfth century, writers aligned themselves on pro- and anti- Tristan factions. Many cited the famous couple as the perfect example of love until death, while others critcized the adulterous relationship, saying it was the consequence of a potion and not of a union of hearts. Dante placed Tristan in hell, at the head of a company of over a thousand knights and ladies who had died as a result of their lustful relationship. While medieval moalist writers severely
\end{abstract}

* En mi libro La caballería fingida como «educación sentimental» avancé algunos aspectos que aparecen en este artículo. 
criticised readers of the romance, the noble families of Europe decorated their mansions with tapestries, fresco paintings and other objects decorated with the best-known and most significant scenes from Tristan legend.

Key words: Tristan and Iseut. Old French poems. Reception in the Middle Ages. Praise, imitation, criticism. Famous lovers. Twenty-first centry readers.

Leyendo la reciente novela Les bienveillantes («Las benévolas») de Jonathan Littell, galardonada con el Premio Goncourt y el Gran Premio de novela de la Académie Française, había advertido en ella ciertas alusiones o ecos de temas medievales, siempre bien llevados y oportunos. Casi al final del largo libro, en la página 835, me encontré con un episodio que me llamó la atención. Max Aue, un oficial de las SS, está destinado en Berlín durante la Segunda Guerra Mundial. Tiene una vida sentimental inestable y ambigua, de relaciones homosexuales esporádicas e insatisfechas, porque desde siempre ha estado enamorado de su hermana gemela. En Berlín empieza a salir con Hélène, una chica que conoce en la piscina, con la que nunca llega a mantener ningún tipo de contacto físico.

\section{[Max Aue lo cuenta]}

Un día en que íbamos andando por una calle, un coche pisó un charco a nuestro lado; el agua que saltó se le metió debajo de la falda, salpicándola hasta los muslos. Soltó una carcajada incongruente y casi cortante. — «Por qué se ríe así? ¿Qué le hace tanta gracia?» — «Usted, es usted, —me soltó entre risas-. Nunca me habían tocado tan arriba».

La escena del charco, la salpicadura oportuna y atrevida corresponde a un breve episodio del Tristán que Tomás de Inglaterra había escrito unos ochocientos cincuenta años antes. Tristán contrae matrimonio con Iseo de las Blancas Manos, creyendo que así podrá olvidar a Iseo la rubia, pero, obsesionado por su amor a la reina y comido por los celos que siente al pensar que ella vuelve a estar junto al rey Marco, no puede consumar su matrimonio:

Y ocurrió que en aquel país don Tristán y don Kaherdín se dirigieron con sus vecinos a un festejo para participar en las justas. Tristán llevaba consigo a Iseo de las Blancas Manos. Kaherdín cabalgaba a su lado y sostenía las riendas con la mano izquierda; iban hablando alegremente. Tan absortos estaban en su conversación que dejaron que los caballos trotaran libremente. El caballo de Kaherdín se separó de los otros y el de Iseo se encabritó y le siguió. El palafrén dio un salto hacia delante y al caer resbaló en un charco. Cuando las patas alcanzaron el charco, el agua salpicó los muslos de Iseo que estaban separados para espolear al caballo, Iseo al sentir el agua fría tuvo un estremecimiento, dio un grito y no dijo nada pero se puso a reír con tanta fuerza que no hubiera podido callarse. Cuando Kaherdín la vio reír de esta manera pensó que había oído alguna necedad o palabras viles porque él era un caballero honorable, noble y amable, y en la risa de su hermana vio, con temor, algo de insensatez; le avergüenza este pensamiento y le pregunta: 
- Iseo, de lo más hondo del corazón salen vuestras risas y no sé por qué motivo reís, Si no me lo decís no confiaré jamás en vos.

- Iseo comprendió estas palabras y pensó que si le ocultaba la verdad él no le tendría aprecio, y dijo:

—Río porque el agua que salpicó mis muslos subió más arriba que las manos de ningún hombre; ni siquiera Tristán quiso hacerlo.

¡Qué fascinación sigue ejerciendo la novela medieval en algunos escritores! ¡Qué bien la leen y saben entresacar, aprovechar, adaptar episodios, frases, escenas o gestos para incluirlos en sus obras como homenaje a sus autores! O cómo las disfrazan con ropajes y escenarios intemporales, en los años cuarenta del siglo XX, como hizo Jean Cocteau en L'Éternel Retour porque «las mismas leyendas pueden renacer sin que sus héroes lo sospechen».

Si durante la Edad Media el Tristán obsesionó a la Europa culta, y de todas las novelas de la época fue la más citada, elogiada e imitada, también hay que constatar que fue también la más criticada y la que causó mayor escándalo. Recientes estudios de antroponimia literaria de la Edad Media revelan que Tristán es el personaje con mayor número de menciones, ciento veinte, seguido de Lanzarote con setenta y nueve, y muy atrás el rey Arturo y Perceval. Pero no sólo fue asunto de escritores mencionar a Tristán e Iseo. Desde la segunda década del siglo XII, padres y padrinos bautizaron a los niños con los nombres de Tristannus, Tristrant, Tristaynus (en Francia e Italia), Tristany (en Cataluña); incluso unos padres del condado de Blois dieron a dos de sus ocho hijos los nombres de Tristannus e Isaut, antes de 1170 . Entre 1187 y 1250 vivió la trobairitz provenzal Iseut de Capio; y, a finales del siglo XIII, Juan, uno de los hijos de Luis IX tuvo el sobrenombre de Tristán «pour la grant douleur ou il fu né», como escribe Joinville en su Vie de saint Louis (cap. 399). Y es que Tristán es un nombre «parlante»que prefigura un destino de amargura, y que vio acertadamente el autor de la Folie de Berna cuando al fingirse loco Tristán cambia su nombre por el de «Tantris»: Change son non, fait soi clamer /Tantris, vv. 126-127.

No fue la muerte tan inmediata de ambos amantes lo que más se recordó, - y tantas veces será imitada por grandes escritores-, ni tampoco el adulterio sorprendió y escandalizó al auditorio, porque desde los primeros trovadores ya se había idealizado o por lo menos consentido literariamente, aunque nunca de manera tan cruda, sino veladamente y como elección frente a un matrimonio impuesto. Si en algunas canciones la relación sexual era explícita o veladamente aludida (y anhelada), se defendía sobre todo el dominio del deseo y la sublimación en la espera y en la distancia.

La singularidad del Tristán está en que el amor entre Tristán e Iseo nace del azar, es fruto de una bebida equivocada que no les estaba destinada y que sirve a los enamorados para disculpar su amor, para insistir ante todo el mundo, ante su confesor, ante el rey Marco y ante ellos mismos, que no sintieron fole amor, amor insensato e inmoral, sino amor en bone foi, «buen amor», que la culpa sólo 
la tuvo el lovendrins, el vin herbez, el boivre d'amor: la bebida, pócima o filtro, que les intoxicó y desató en ellos un deseo ciego que les empujó a amarse. A partir de la bebida fatal y la consumación de su amor se origina un conflicto entre los amantes y la sociedad, una serie de renuncias y una marginación progresiva, que les conducirá a la muerte. La consecuencia de la huida de los amantes al bosque de Morrois, donde vivirán durante años, es que Tristán deja la corte sin los servicios del mejor de sus caballeros, al rey Marco sin su heredero y a los jóvenes que van a ser caballeros sin un guerrero excepcional que les enseñara a manejar las armas y a vencer a cuantos dragones o gigantes se les pusieran al paso, como había hecho el mismo Tristán antes de apurar la «bebida de amor». Tristán enamorado se desinteresa por todo lo que había constituido su vida anterior: «He olvidado las caballerías y estar en la corte entre los barones» (Berol, vv.2165-2166). Iseo, por su parte, es infiel al rey Marco, su marido y señor, sin ser en ningún momento una «malcasada» como las de tantas canciones, novelas, lais o romances para las que siempre había una justificación de su adulterio. Iseo al huir de la corte con Tristán priva a ésta de las funciones de la reina que también debía preocuparse por la educación y el matrimonio de sus doncellas.

Quizá sea esto lo que hace que el Tristán sea un relato universal no tan anclado en la sociedad de los caballeros de la Tabla Redonda que armonizaban el amor, las caballerías, la fama y (algunos) la espiritualidad. Esta concepción tristaniana del amor, urgente y satisfecho, a escondidas y con privaciones, y con su conflicto íntimo dentro de un reducido círculo familiar, es una novela más realista y más humana.

Una historia que, por otra parte, no fue redactada por un único autor y de una sola vez. A los relatos «largos», y fragmentarios, de Berol y Tomás (de Inglaterra) se añadieron, independientemente y sin que dejemos el siglo XII, varios relatos en torno a los personajes principales de la historia. La estructura episódica y las características del argumento facilitaron estas ampliaciones en poemas independientes. En una progresiva y rapidísima operación de reescritura se entretejieron una serie de relatos, no muy extensos, diferentes todos, en los que los principales protagonistas siempre eran los mismos, no sólo en sus nombres sino en su manera de ser y de actuar. Tristán, un héroe nuevo con habilidades atléticas simples que durante la vida en el bosque, le serán muy útiles. Tristán lanza discos de piedra, salta fosos, combate a pie, caza con arco, sabe desollar animales y tallar armas, inventa el arco-que-no-falla (una trampa para cazar) y amaestra a su perro. Se destacan sus actividades de bardo pues sabe tocar el arpa y la viola, canta e imita a los pájaros; y aún más, es trovador pues compone la música y la letra de sus canciones. Y como caballero es admirada su destreza con las armas y sus comportamiento en la corte jugando al ajedrez, a las damas y a los dados. Pero Tristán es también el héroe ingenioso, el de las mil argucias, que con sus disfraces y múltiples caracterizaciones, de loco, peregrino, arpista, juglar, monje, mendigo e incluso de leproso, logra cada vez engañar al rey Marco para llegar hasta los brazos de Iseo.

Iseo es, quizá, la figura femenina más universal de la literatura medieval, tan literaria y a la vez tan humana, tan real. En todos los poemas se da la misma imagen de la única hija del rey de Irlanda, que hereda de su madre la habilidad 
de curar con hierbas las heridas causadas por misteriosos venenos. La reina es rubia y bella, como se complace Berol en repetir, describiéndola físicamente y en sus actitudes. En todo momento dueña de sí misma, dirigiendo los pasos de Tristán, hábil en sus palabras, prudente, pero en ocasiones temeraria, astuta, egoísta, mentirosa y capaz de llevar una doble vida afectiva como esposa de Marco y amante de Tristán. Ejerce y utiliza su atractivo con todos los hombres que la rodean: con el senescal Dinas de Dinán, con el paje Perinís, «con el pretendiente que la quería desposar» en contra de sus deseos; con el arpista irlandés que se la llevó en su nave «lleno de gozo», con un tal Gamarién ..... Continuando con la lista de los personajes que sucumben a sus encantos está Cariado, el pretendiente obstinado, y el mismo rey Arturo de Bretaña que dice que hará «todo lo que ella desee, pues estoy lleno de ímpetu y ella me dará prestigio. Recuérdale [...] pues ella sabe perfectamente lo que pasó» (Berol). Otros pretendientes aparecen aludidos en versiones posteriores, algunas veces de forma muy concreta, lo que indica la intención de la leyenda tristaniana por destacar el singular atractivo y belleza de la reina Iseo. Completa la caracterización de Iseo su lado de mujer enamorada, impulsiva, pero también asustadiza, insegura y abatida que vemos durante la estancia en el bosque de Morrois o en la melancolía y ensueños en los que se refugia en ausencia de Tristán, y que relata magistralmente Tomás de Inglaterra. De esta discontinuidad psicológica en sus palabras y en sus actos proviene la unidad del personaje, porque en todo momento hay en Iseo un conflicto, en parte inconsciente, entre dos fuerzas opuestas, Tristán y Marco: la pasión arrolladora y transgresora y el amor y la seguridad. Contradicción, lucha interna, plasmada espléndidamente por Berol en el sueño de Iseo en el bosque.

El rey Marco es una de las figuras más complejas de la literatura medieval. El rey de Cornualles tiene orejas de caballo, signo bestial que supone la posesión a la vez de cualidades humanas y animales: amor y ternura pero también crueldad irracional y furia. No posee criterio fijo, ni como rey con sus vasallos, ni como señor y tío de Tristán, ni como esposo de Iseo: perdona o castiga según le empujen a ello el rey Arturo o los Barones Felones. El inmenso amor que Marco siente hacia su sobrino y su mujer le inclina a dominarse en sus impulsos, a creer las ambiguas palabras y actitudes de los amantes cuando les sorprende en la cita bajo el pino o durmiendo abrazados en el bosque de Morrois. A pesar de ello, de tener el difícil y feo papel de marido engañado, el arte de los escritores no lo convierten en una figura ridícula o burlesca propia de un fabliaux, un cuento «verde», sino en víctima, víctima digna, del inmenso amor que siente por ambos y que le inclina a dominar con frecuencia su cólera y a no querer creer lo que oye o lo que tiene ante sus ojos. El personaje de Marco, en las versiones más antiguas, está muy lejos de los «maridos celosos» que se encuentran en el lai de Yonec de María de Francia, en el Cleomadés de Adenet le Roi, en la novela provenzal Flamenca, en las canciones de malmariée o en otros textos medievales.

Ninguno de los escritores del Tristán recurrieron nunca a personajes o episodios sobrenaturales. Se procuró en todo momento mitigar el papel de lo «maravilloso», buscando lo verosímil: ni en el filtro, ni en la lucha con el dragón o con el gigante Morholt, ni en el salto de Tristán parece que hayan intervenido ni milagros ni poderes del Otro Mundo. Si su atractivo se ha mantenido hasta 
nuestros días, si todavía interesa y emociona es porque se trata tan solo de una historia de amor y de muerte, como la definió Joseph Bédier en 1900. Y porque en la historia supieron sus autores combinar sabiamente las alegrías y las penas, erotismo y ternura, tomando ideas de todo tipo, de modo que las posibles fuentes célticas quedaron borradas o se incorporaron al ambiente de su auditorio, una sociedad románica, cristiana y feudal, junto con otros préstamos clásicos y folclóricos. El entorno social del Tristán, su forma narrativa, su ética profana del amor, el conflicto entre libertad individual y las instituciones corresponden a una coherente estética literaria y a un momento determinado, y van dirigidos a un público concreto que propició este movimiento literario y que entendía el lenguaje y los conceptos que le ofrecía el Tristán.

Los poemas breves tristanianos que se fueron creando en torno a la historia permitieron complacer al auditorio y dilatar el tiempo hasta que llegara la muerte de los amantes a la que, por muy conocida o prevista que fuera, no se quería nunca llegar. Quizá influyera en ello el público, como hicieron más tarde los lectores de La Celestina que querían que Fernando de Rojas «alargasse en el proceso de su deleyte destos amantes, sobre lo qual fuy muy importunado...». Y así, otros escritores, María de Francia entre ellos, escribieron episodios para volver a oír una vez más que Tristán e Iseo se encontraban a solas para amarse, escapando de los celos del rey Marco y de las miradas de la corte de Cornualles.

Historia más para ser escuchada que leída, con la que los juglares debieron esmerarse en modular la gran riqueza de registros y de juegos de rimas, dentro de esta «estética de la repetición» propia del roman francés de la segunda mitad del siglo XII. El auditorio había de estar atento al discurso entretejido de palabras sobreentendidas o equívocas, como en este magistral y polisémico trabalenguas o adivinanza de Tomás de Inglaterra entre l'amer, la mer y amer («amar», «la mar»y «amargo») que tan repetido será en obras literarias posteriores y que Gottfried von Strassburg, que no querrá desecharlo en su Tristan, tendrá que conservarlo con los términos franceses.

Habla Iseo a Tristán en la nave que les lleva a Cornualles.

«Cum bien creustes vus, amis,

si vus ne fussez, ja ne fusse,

ne de l'amer rien ne seusse.

Merveille est k'om la mer ne het

qui si amer mal en mer set,

e qui l'anguisse est si amere!

Si je une foiz fors en ere,

Ja n'i enteroie, ce quit.»

Tristan ad note chescun dit,

mes el l'ad issi forsvée 
par l'amer que ele ad tant changé

que ne set si cele dolur

ad de la mer ou de l'amur,

ou s'el dit amer de la mer

ou pur l'amur diet amer.

Pur la dotance que il sent,

demande si l'amur li prent

ou si ja grante ou s'el s'astient.

$\cdots$

Car deus mals i put l'en sentir,

l'un d'amer, l'autre de puïr.

Ysolt dit:« Cel mal que je sent

est amer, mes ne pur nïent:

mon quer angoisse e pres le tient.

E tel amer de la mer vient:

prist puis que je çäenz entray».

Tristan respont: «Autretel ay:

ly miens mal est del vostre estrait.

L' anguisse mon cuer amer fait,

si ne sent pas le mal amer;

n'il ne revient pas de la mer,

mes d'amer ay ceste dolur,

E en la mer m'est pris l'amur.

Assez en ay or dit a sage. Tristán, fragmento de Carlisle, vv. 38-71

«Bien lo creyerais, amigo,

si vos no hubierais venido yo tampoco estaría aquí

y no sabría lo que es amar.

¡Es asombroso que no odie la mar

quien un mal tan amargo conoce en la mar

y a quien la angustia es tan amarga!

Si yo me pudiera librar de ello, 
no volvería jamás, eso creo».

Tristán ha estado atento a cada una de las palabras

pero ella le ha confundido de tal modo

a causa de este «amar» que tanto ha cambiado

que no sabe si este dolor

es por la mar o por amar,

y si ella dice amar queriendo decir la mar

o en vez de decir amar dice amargo.

[Tristán], temeroso, se pregunta

si el amor hubiera prendido en ella,

lo aceptaría o lo rechazaría.

pues estos dos males se pueden sentir a la vez:

uno produce mareo, el otro repugna.

Iseo dice : «El mal que siento

es amargo, pero no me repugna en absoluto :

angustia mi corazón y lo oprime

y este amargor me viene de la mar :

empezó el día que entré en ella».

Tristán contesta : «Siento lo mismo.

Mi mal tiene el mismo origen,

la angustia amarga mi corazón,

pero no siento que este mal sea amargo;

[este mal] no procede de la mar

sino de amar tengo este dolor,

y fue en la mar cuando empecé a amar.

He hablado lo bastante para que se me entienda».

Nosotros tenemos la misma confusión Tristán cuando intentamos traducir las palabras de Iseo que reflejan el desconcierto de sus sentimientos después de haber bebido el «vino de hierbas». Palabras, amer, la mer, l'amer, que repite constantemente y cuyo significado Tristán no acaba de comprender, temiendo y deseando a la vez que lo que ella le intenta decir es que le ama. Y así fue, porque el diálogo magnífico acaba con los jóvenes enamorados «hablando de su felicidad y de sus deseos entre besos caricias y abrazos» vv. 74-75.

También durante un viaje en barco es una mujer, la reina Ginebra, la que, hablando consigo misma esta vez, mezcla la mar y el mar, cuando reflexiona 
acerca de los amores entre su doncella Soredamor y el príncipe de Constantinopla, Alejandro. A pesar de las dificultades en afinar la datación de la obra de Tomás de Inglaterra, su Tristán parece anterior al Cligés de Chrétien de Troyes redactado entre 1174 y 1176.

ne set por coi il le font

fors que por la mer ou il sont.

Espoir bien s'en aperceüst

se la mers ne la deceüst,

mes la mers l'enginne et deçoit

si qu'en la mer l'amor ne voit,

qu'en la mer sont et d'amer vient

et amers est li maus quis tient,

et de cez trois ne set blamer

la reïne fors que la mer. Cligés, vv. 543-554.

...

no sabe qué les pasa

sino que están en la mar.

Quizá se habría dado cuenta,

si la mar no la engañara,

pero la mar embauca y enreda

y en la mar no descubre el amor,

pues están en la mar y amor sienten

y es amargo el mal que tienen,

y de estas tres cosas sólo puede acusar

la reina a la mar.

Algunos trovadores y en el Roman de la Rose, vv. 2194-2196, habían aprovechado este juego de palabras para ilustrar situaciones sentimentales. Dando un salto de siglos, pero más próximo a nosotros, Tirant disimula su emoción ante Carmesina fingiendo estar enfermo. Martorell no deja de echar mano, en una escena en que el mar y amar se vuelven a encontrar, del recurso retórico, ya antiguo, de la confusión debida a la homonimia de las palabras:

—Digau-me, Capità, iquin era lo mal que ahir la vostra persona sentia?—. Dix Tirant: - Senyor, la majestat vostra deu saber que tot lo meu mal és de mar, 
car los vents d'aquesta terra són més prims que los de ponent-. Respòs la Infanta [Carmesina] ans que l'Emperador parlàs: - Senyor, la mar no fa mal als estrangers si són aquells que ésser deuen, ans los dóna salut e llonga vida-. Mirant tostemps en la cara a Tirant, sotsrient-se perquè Tirant conegués que ella l'havia entès. (Tirant lo Blanc, cap. CXIX. Ed. Riquer).

$$
* * *
$$

Cuando aún no había finalizado el siglo XII y no estaban redactados todos los relatos episódicos del Tristán, se desencadenó una polémica sobre el «amor fatal» extendiéndose por los ambientes culturales de las Galias. Los escritores se dividieron en pro y anti tristanianos y los testimonios son numerosos. El listado de trovadores provenzales es largo, desde Cercamon y Gueraut de Cabrera antes de acabar el siglo XII hasta Cerverí de Girona, en las últimas décadas del XIII, no dejaron de aludir a Tristán y a Iseo. Reyes poetas, como Thibaut de Champagne, rey de Navarra, Alfonso el Sabio y su nieto el rey Don Denís de Portugal y este misterioso «Re Giovanni», identificado con el conde francés Jean de Brienne, rey de Jerusalén desde 1210, en sendas canciones también equipararon sus penalidades amorosas con la de los amantes de Cornualles.

Bernat de Ventadorn, el trovador que más veces mencionó la historia, declaraba que

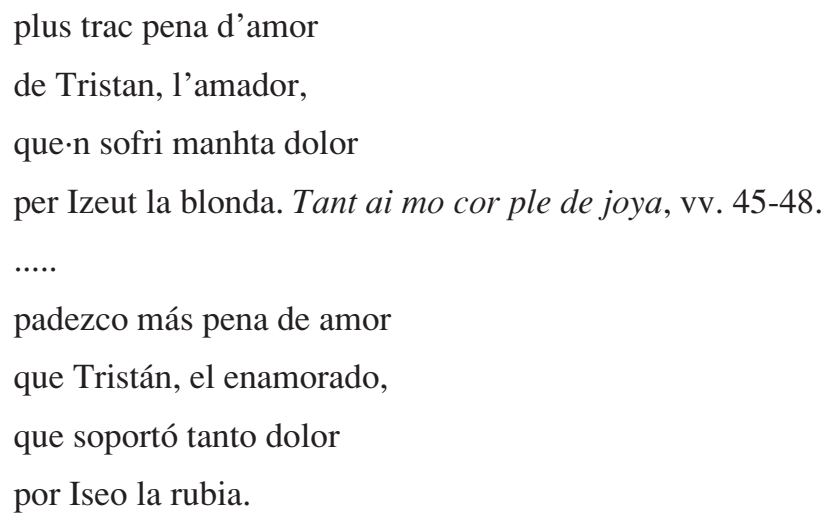

Este trovador se dirigía con el senhal (seudónimo) de «Tristán» a su colega Raimbaut d'Aurenga, trovador que, a su vez, aludió varias veces en sus canciones a episodios de la inmortal pareja. A los trovadores les obsesionó el vin herbé, el «vino de hierbas» que había empujado a Tristán y a Iseo a amarse porque al ser ajeno a la voluntad iba en contra de la poética de la cansó trovadoresca del amor elegido Así, la expresión «beber del amor» o «beber el amor», fue empleada con intencionada alusión por Raimbaut d'Aurenga: 
Car ieu begui de la amor

ja $\cdot$ us dei amar a celada.

Tristan, qan la·il det Iseus gen

e bela, no.n saup als faire;

et ieu am per aital coven

midonz, don no·m posc estraire. No chant per auzel ni per flor, vv. 27-32.

Pues si bebí el amor

os debo amar a escondidas.

Cuando a Tristán le dio (el amor ¿la bebida?) a Iseo, gentil

y bella, no supo hacer otra cosa;

y amo por tal pacto

a mi señora, que no me puedo alejar de ella.

La bella expresión «beber el amor» es casi un calco por parte de nuestro trovador, de un verso de la Eneida: infelix Dido longumque bibebat amorem (I, v. 749), «bebiendo el largo amor la infortunada Dido».

Arnaut Daniel proclamó orgulloso que no dejaría nunca de amar a su señora porque su «firme deseo no era de redoma» (mon ferm voler que non es de retomba, en Si.m fos amor de joi donar tan larga, v. 36); es decir, que su amor no era fruto de un bebedizo contenido en una frágil redoma, como el que bebieron Tristán e Iseo, sino que se debía a la voluntad, al ferm voler.

Entre los novelistas franceses, quien se mostró más directamente contrario a la historia de Tristán y de Iseo fue Chrétien de Troyes. Si, en un poema —no olvidemos que también fue trouvère, aunque su fama de narrador eclipsó a la de poeta-, se adhirió a los trovadores al rechazar el filtro fatal que «envenenó» a Tristán

Onques du brevage ne bui

dont Tristan fu enpoisonnez;

mes plus me fet amer que lui

fins cuers et bone volentez. D'Amors qui m'a tolu a moi, vv. 28-31.

Nunca bebí de la bebida

con la que Tristán fue envenenado,

pero más que él me hace amar

leal corazón y buena voluntad. 
fue con una novela, Cligés, donde demostró claramente su intención de hacer desaparecer el mito, presentando una relación familiar y vasallática similar a la del modelo, pero orientada hacia la fidelidad conyugal y el dominio de la pasión con escenas y palabras directamente explícitas:

Fenice, enamorada de Cligés, sobrino de su marido, no quiere consumar el amor y dice estas palabras:

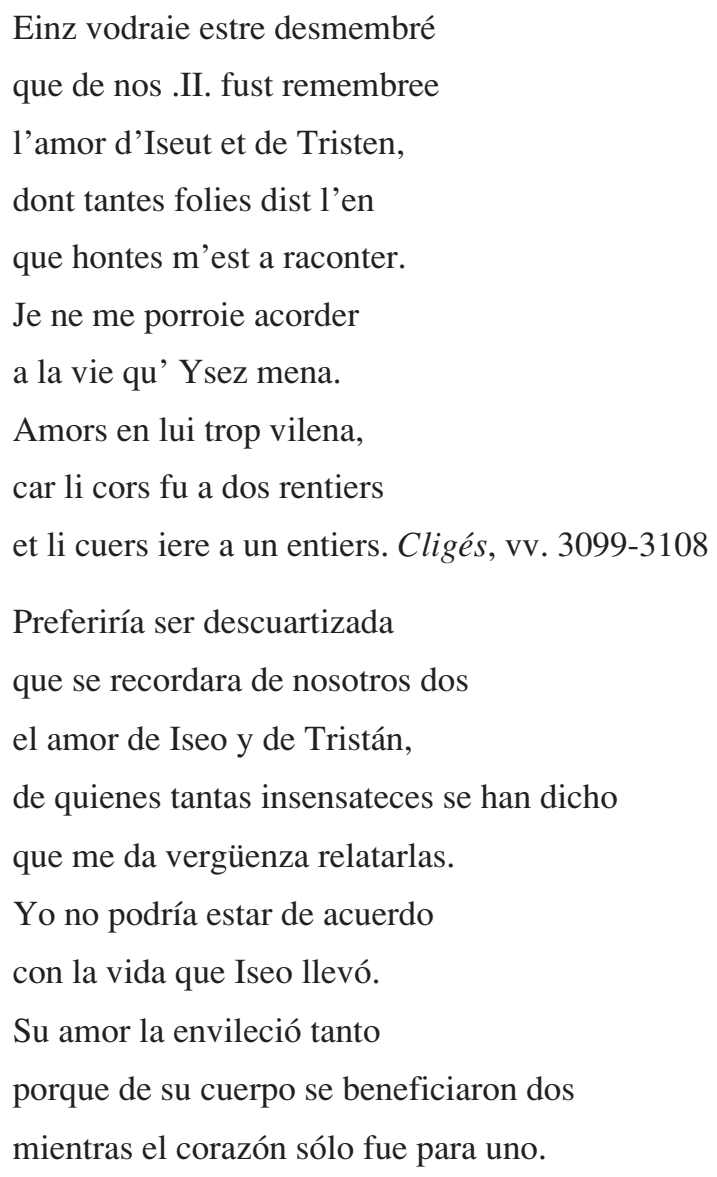

Este era el gran reproche de Fenice a Iseo y el de Chrétien al Tristán. El Cligés fue el gran fracaso de este escritor que no pudo imponer su novela y desbancar a la gran pasión del siglo XII tan rápidamente divulgada ya por toda Europa. Lo demuestra la indignación, hacia 1160, del teólogo Pedro de Blois cuando veía que la gente se ponía a llorar en las plazas escuchando a los juglares contar las historias de Arturo y de Tristán en vez de hacerlo en la iglesia al oír la pasión de Cristo.

Dante condenó los amores Tristán llevándole al segundo círculo del infierno, encabezando un cortejo de más de mil damas y caballeros que habían perdido la vida por sus amores lujuriosos. 
«Vedi Paris, Tristano»; e piú di mille ombre

mostromi e nominomi a dito,

ch'amor di nostra vita dipartille. Dante, Inferno, V, vv. 66-68.

«Ve a Paris, a Tristán». Y así ha nombrado

de aquellas almas un millar corrido,

que amor de nuestra vida ha separado. Trad. de Ángel Crespo (Planeta, 1983)

Petrarca, en los Triunfos (1352-1353), continuó con las condenas a los héroes caballerescos y sus amores. Con una escenificación parecida a la de la Comedia, un vero amico le muestra a Petrarca un cortejo de amantes célebres, entre ellos Tristán, Lanzarote y «otros errantes» que habían llenado «los libros de sueños». Ambigua condena de Petrarca a los libros de caballerías, los de Tristán y Lanzarote especialmente, que tanto hacían disfrutar y fantasear al «vulgo», a los iletrados.

Ecco quei che le carte empion di sogni :

Lancilotto, Tristano e gli altri erranti,

ove conven che 'l vulgo errante agogni.

Vedi Ginebra, Isolda e l'altre amanti,

e la coppia d'Arrimino, che 'nseme

vanno facendo dolorosi pianti. Petrarca, Triumphus Cupidinis, vv. 79-84.

...y los que llenan páginas de sueños:

Lanzarote, Tristán y tantos otros,

con los que el vulgo se apasiona y yerra.

Mira a Ginebra, a Isolda y a esas otras,

y a aquellos dos de Rímini que juntos

un llanto dolorido van soltando. Trad. de J. Cortines (Cátedra 1989)

Petrarca, como tantos escritores, también mezcló los personajes literarios con los reales, representados estos por la coppia d'Arrimino, condenada al infierno por Dante por leer el Lanzarote en prosa. A Tristán e Iseo, Lanzarote y Ginebra, las dos parejas de enamorados más famosas de la literatura medieval, se unen Paolo y Francesca, tan literarios ya como sus modelos, o estos tan reales como «la pareja de Rímini».

El franciscano Francesc Eiximenis, escribió que,

[Els homes perden] lo temps en legir coses inútils e falses e trufadores, axí com fan aquells que ligen lo libre de Na Guineu o lo libre de Tristany o de Ro- 
tlan o semblants pagueses; car, com diu sanct Ambròs, hom chrestià, a qui Déus ha dades e lexades tantes meravelloses Scriptures e tantes precioses qui parlen de tot ço que l'hom pot desitjar, fort és culpable si totes aquestes coses aytals lexa e recorra a libres trufadors e monçoneguers. Primer del Chrestià, cap. CCCXLII, entre 1379 y 1381.

[Los hombres] pierden el tiempo leyendo cosas inútiles, falsas y engañadoras, como hacen aquellos que leen el Roman de Renart o el libro de Tristán o de Roldán o tonterías semejantes; pues, como dice san Ambrosio, hombre cristiano, a quien Dios ha dado y dejado tan maravillosas Escrituras y tan preciosas que hablan de todo lo que el hombre puede desear, es muy culpable si todas estas cosas deja y recorre a libros engañadores y mentirosos.

En Lo somni, redactado en 1399, Bernat Metge, pone en boca de Tiresias una dura diatriba contra las mujeres lectoras, inspirada directamente en unos pasajes del Corbaccio:

Elles entenen ésser en gran felicitat haver molt delicament e loçania, e saber parlar diverses lengatges, recordar moltes cançons e noves rimades, al-legar dits de trobadors e las Epístolas de Ovidi, recitar les ystòrias de Lançelot, de Tristany, del rey Artús e de quants amorosos són stats a lur temps. III.

Ellas se creen muy felices teniendo mucha delicadeza y lozanía, y sabiendo hablar varias lenguas y recordando muchas canciones y novas rimadas, alegando citas de trovadores, y las Epístolas de Ovidio, relatando la historias Lanzarote, de Tristán, del rey Artús y de cuantos enamorados ha habido hasta su tiempo.

Y así podríamos continuar un par de siglos más con los ataques a los pestiferis libris, como los llamó Juan Luis Vives, protagonizados por Tristán, Amadís, Tirant, Esplandián, Lancilotus a Lacu y otros caballeros librescos. En su Instrucción de la mujer cristiana, 1528, el valenciano se quejaba de que en su tiempo «ya no se leen otros libros sino vulgares, do no hallaréis otra materia sino de armas y de amores». A pesar de ello, estos libros continuaron leyéndose, imprimiéndose y guardándose en las bibliotecas de los palacios, de las casas sencillas e incluso en los conventos de monjas, porque, siglo tras siglo, continuaron siendo, también, lecturas de mujeres, y las lectoras no dejaron de ser criticadas, «porque no ay quien tanto siga lo que lee como la muger», como escribió Francisco de Osuna.

El Tristán que estos y otros más, tanto escritores como moralistas, condenan no es el de Berol, Tomás de Inglaterra y los anónimos de los poemas episódicos. Cuando se redactó en prosa la historia de Tristán se dejaron de copiar y de leer en Europa las versiones en verso porque ya no eran del gusto del público, como ocurrió con los otros textos de la narrativa artúrica.

$$
\text { * * * }
$$

El Tristán en prosa, redactado durante el primer tercio del siglo XIII, aunque basado en las versiones de Berol, Tomás y las Folies, diluyó la presencia de la pareja de enamorados que, siempre juntos o buscándose, representaba la 
idea de un amor eterno e inseparable, de modo que sin uno de ellos el otro no existía. Su modelo fue el Lanzarote en prosa del que el Tristán tomó el marco, los temas, los personajes, los episodios y la exaltación sentimental y caballeresca, e insertó la historia de los amantes de Cornualles en el tiempo y en la geografía de Arturo de Bretaña, de manera compleja y con enorme extensión. El rey Marco fue el único de los personajes que experimentó una radical transformación. Si en las versiones en verso siempre parecía dispuesto a no dar crédito a las murmuraciones en torno a las amantes y a perdonarlos, aquí se revela traidor y cruel con ellos, llegando incluso a asesinar a Tristán atravesándole el pecho con una espada envenenada, la «mala lanzada» del Romancero castellano, al descubrirle en la cámara prohibida, la de Iseo. Este Tristán, libro de caballerías ya, se muestra despojado casi por completo de la pasión y de la frescura de los poemas primeros, como también del estilo simple y lineal en el que se sucedían los episodios. Las caballerías, la búsqueda del Grial y otras muchas empresas hacen de Tristán, con sus armas heráldicas de gules con un león de oro, un caballero excepcional que ama a Iseo, pero entre otros oficios, no únicamente el de l'amerous, «el enamorado», como le llamó Tomás de Inglaterra (ms. Carlisle, v. 96)

Si la historia literaria del Tristán se prolongó durante siglos lo mismo ocurrió con su plasmación iconográfica. Lujosos enseres de uso doméstico y los manuscritos que copiaban la historia reprodujeron en bellísimas dibujos las escenas culminantes de sus historias, las mismas que repitieron tantas veces los poetas. Las historias de los caballeros de ficción ocuparon el sitio de la historia sagrada en los pórticos y en las misericordias de las catedrales; y con las armas relucientes y los colores de su heráldica propia entraron los caballeros de la Tabla Redonda en los castillos y mansiones señoriales, figurando en los pavimentos, en las paredes, en los artesonados y en los tapices. Ciñéndome sólo al Tristán, desde el fuste de la Porta Francígena de la catedral de Santiago en el que aparece un personaje que está en una nave y que podría ser Tristán, hasta el castillo de Saint Floret en la Alvernia se han documentado numerosos episodios de la leyenda de Tristán e Iseo. Las pinturas en las paredes de las casas señoriales se convirtió en un motivo literario y la inmortal pareja se unió a estas «galerías de enamorados» que ya llevaban siglos amándose. Unos ejemplos de las dos novelas catalanas más importantes del siglo XV. En el Curial, Güielfa tiene un sueño alegórico de su situación sentimental en el que se ve contemplando, con la abadesa, un baile en el que ambas conocen a todos los que participan:

Aqui virats Tisbes e Píramus fer-se maravellosa festa, Flors e Blancaflor, Tristany e Ysolda, Lançalot e Genebra, Frondino e Brisona, Amadís e Uriana, Phedra ab Ypòlit, Achil·les tot sol menaçant son fill Pirro, Tròyol e Briseida, Paris e Viana, e molts altres, del quals, per no ésser lonch, me callaré» (Curial e Güelfa III, p. 230. Ed. Aramon).

Y Tirant, en el palacio del emperador de Constantinopla, entra en una

cambra molt ben emparamentada e tota a l'entorn hestoriada de les seguents amors: de Floris e de Blanxesflors, de Tisbe e de Píramus, d'Eneas e de Dido, 
de Tristany e d'Isolda, e de la reina Ginebra e de Lançalot, e de molts altres, que totes llurs amors de molt sobtil e artificial pintura eren divisades (cap. CXVIII).

Y en los grandes festejos que organiza el Emperador, en el episodio llamado el «Entremés del rey Artús» en un estrado hay una gran cantidad de mujeres, unas disfrazadas de diosas, con la Sibila en lo alto, y junto a ellas,

....les dones qui bé havien amat, així com fon la reina Ginebra, qui a Lançalot amà, la reina Isolda a Tristany, e la reina Penèlope, qui a Ulixes amà, e Elena a Paris, Briseida a Aquil·les, Medea a Jason, la reina Dido a Eneas, Deiamira a Hèrcules, Adriana a Teseu, e la reina Fedra, qui requerí a Hipòlit, son fillastre; e moltes altres n'hi havia que seria fatiga de nomenar-les, que en la fi de llurs amors foren decebudes per los enamorats. (cap. CLXXXIX).

La función de estas estatuas vivientes del Tirant era la de azotar a los caballeros que habían sido derrotados en el torneo.

En algunas obras francesas de la segunda mitad del siglo XII, el momento en que escribe Tomás de Inglaterra — en el Roman d'Eneas, el Roman de Thèbes, el Roman de Troie, el Roman d'Alexandre, en novelas seudohistóricas como el Roman de Brut y el Roman de Rou de Wace, en algún cantar de gesta como el Pélérinage de Charlemagne, o en romans y cuentos de aventuras como Ipomedon, Floire et Blancheflor o el Eracle de Gautier d'Arras- se describen suntuosos castillos y palacios que tienen como elementos decorativos paredes pintadas con escenas de todo tipo. En muchas de estas novelas las estancias también se decoran con estatuas de hombres y de mujeres, en tamaño natural, que en muchos casos son autómatas que danzan o hacen malabarismos, tocan instrumentos musicales que suenan, o empuñan armas. Fue una moda literaria que a veces se identificaba en lo que se denominan «elementos maravillosos», pero que, en muchos casos no había en ellos nada mágico ni milagroso: existían en la realidad, se construían en el Imperio bizantino gracias a la habilidad en la mecánica y en la ingeniería de ciertos artesanos y que se había llevado a las cortes europeas: pero esto no lo sabía todo el mundo. Y vuelve a ser en el Tristán, en el Tristán medieval en verso, donde encontramos la más sugestiva representación de una «Sala de las Imágenes» no como digresión ornamental del relato ni como un ejercicio más de écfrasis en que se esmeraba el escritor para que resaltar el lujo de un palacio, sino representando una historia que está sucediendo en aquel momento y con los protagonistas aún vivos.

Pasados ya los años felices y también amargos en el bosque de Morrois, Iseo ha regresado junto al rey Marco y Tristán se ha exiliado a Bretaña, en donde vive obsesionado por la ausencia de la reina y atormentado por sus celos, lo que le impide consumar su matrimonio con Iseo de las Blancas Manos. Tristán va cada día a cazar al bosque.

En medio del bosque hay una gruta excavada en la roca cerrada con una gran piedra. Con la ayuda del gigante Moldagog y de todo un equipo de artesanos, ebanistas, escultores y orfebres, Tristán transforma la gruta en una lujosa sala, iluminada como si estuviera a plena luz y ordena, luego, modelar unas estatuas 
con las figuras de los protagonistas de su historia amorosa. La de la reina Iseo se ha hecho «con tanto arte que se le parecía en el porte y en la belleza como si estuviera allí en persona, tan fresca como si estuviera viva». Tristán había hecho un hueco en su seno izquierdo, junto al corazón, en donde puso una cajita con los aromas más dulces de las hierbas más apreciadas en todo el mundo. De esta cajita salían dos tubitos de oro puro por donde circulaba el perfume, uno llegaba hasta la nuca en donde los cabellos nacen, y el otro a la boca por cuyos labios salía un aliento tan dulce que su aroma inundaba la sala.

La imagen estaba exquisitamente vestida y arreglada, como conviene a una reina. Llevaba en la cabeza una corona de oro puro con piedras de todos los colores y en el florón de la frente, una gruesa esmeralda. En la mano derecha un cetro rematado por flores delicadamente trabajadas y en la punta del cetro un pájaro con plumas multicolores movía las alas como si tuviera vida. En la mano izquierda llevaba un anillo en donde estaban escritas las palabras que la reina Iseo le había dicho al separarse: «Tristán, tomad este anillo, guardadlo por mi amor y no olvidéis las penas y las angustias y los dolores que habéis padecido por vos y por mí». A sus pies estaba la estatua del enano malvado y delator. Al lado, hecho de oro, el perrito Petit-crû con un collar cuyo cascabel tintineaba. Al otro lado Brangén, la doncella, en la actitud de ofrecer a Iseo una copa en la que estaban escritas las palabras que antaño le había dicho: «Reina Iseo, tomad esta bebida». La gruta estaba guardada por la estatua del gigante Moldagog que, para amedrentar a los curiosos, de cuando en cuando rechinaba los dientes y lanzaba furibundas miradas; a su lado, un león de cobre que cualquiera hubiera creído que estaba vivo.

¿Qué hace Tristán cuando entra en la gruta? El fragmento de Turín nos lo dice con las escuetas pero tan expresivas y bellas palabras de Tomás de Inglaterra.

Tristán le recuerda a la estatua de Iseo los placeres de su gran amor y también sus sufrimientos y dolores y sus penas y afanes. Cuando es feliz la llena de besos, cuando está triste se enoja con ella, pues Tristán, en sus pensamientos o soñando o dando crédito a las mentiras, piensa que Iseo le ha olvidado o que tiene otro amigo o que no pueda evitar amar a otro que esté más a su alcance. Esta idea le espanta; esta turbación altera su ánimo (...). Cuando tiene estos pensamientos tan tristes muestra su odio a la imagen [de Iseo] y se pone a contemplar la otra [de Brangén]. Y como no quiera verla ni hablar con ella, entonces habla con Brangén (...). Luego se aleja un poco y contempla la mano de Iseo, que parece que quiere entregarle el anillo y ve el rostro y la expresión que tenía cuando su amante se alejó de ella (...). Por esto fabricó él esta estatua, para decirle lo que siente su corazón, sus buenos pensamientos y sus desvaríos, las penas y el gozo del amor, porque no sabe a quién descubrir su deseo». (La Pléiade 1995: 153-154; Riquer 2001:157).

Porque la «Sala de las Imágenes», el santuario monumental, lujoso y simbólico, que Tristán hace construir es una síntesis apretada de los episodios más significativos de su vivencia amorosa. Y para ello ha sido necesario que las imágenes, las estatuas, fueran iguales a sus modelos, fueran retratos de los ausentes, en una época en que no existe el retrato, y cuya visión y diálogo no sólo es evocación sentimental sino estímulo del deseo y refuerzo de la fidelidad. 
El Tristán, los «tristanes» en verso, sin hazañas caballerescas ni enfrentamientos militares, se convirtió en la «educación sentimental» de Europa. La acertada expresión la encontré en un artículo del profesor Aurelio Roncaglia en que analizaba este episodio de la «Sala de las imágenes», del Tristán de Tomás de Inglaterra:

Romanzo eminentemente «psicologico» che spicca fra i testi di base su cui s'è compiuta l'«educazione sentimentale» della nostra Europa.

Novela eminentemente «psicológica» que despunta entre los textos en que se ha cimentado la «educación sentimental» de nuestra Europa.

«Lo maravilloso del género novelesco es que es un género caníbal que se apropia de todo y le da otra dimensión» decía hace unos días Mario Vargas Llosa a propósito de su reciente novela El sueño del celta. Una vez más un pasaje de los «tristanes» en verso de uno de estos escritores de los que sólo sabemos su nombre, Tomás (de Inglaterra se lo añadió Gaston Paris) ofreció, con su sabia manera de hacer propias fuentes clásicas y contemporáneas, cultas y populares, de reelaborarlas cuidadosamente dándoles las palabras, los escenarios, los sentimientos y la simbología de su tiempo, el placer de leer una obra literaria que no ha dejado de deleitar y de inspirar a generaciones de lectores y de escritores que llegan hasta el siglo XXI.

\section{BIBLIOGRAFÍA}

Alvar, Carlos, «El Lancelot en prosa: reflexiones sobre el éxito y la difusión de un tema literario», en Serta philologica F. Lázaro Carreter, Madrid, Ediciones Cátedra, 1983, pp. 1-12.

CÁtedra, Pedro M., El sueño caballeresco. De la caballería de papel al sueño real de don Quijote, Madrid, Abada editores, 2007.

Chrétien de Troyes, Oeuvres complètes. Director D. Poirion, ediciones y traducciones de A. Berthelot, P.F. Dembowski, S. Lefèvre, K.D. Uitti y Ph. Walter, París, Éditions Gallimard, «Bibliothèque de la Pléiade», 1994.

Curial e Güelfa, ed. R. Aramon i Serra, 3 vols., Barcelona, Editorial Barcino, «Els Nostres Clàssics», 1930-1933.

LitTell, Jonathan, Las Benévolas, Barcelona, RBA, 2007. (Les Bienveillants, Gallimard, 2006).

Punzi, Arianna, Tristano. Storia di un mito, Roma, Carocci, 2005, Biblioteca Medievale. Saggi.

RIQUER, Isabel de, «Art i amor cortès: Imatges i paraules als segles XII i XIII», en De amore: L'amor a la literatura d'Occident, Barcelona, Societat d'Estudis Literaris/ Barcanova, 1991, pp.101-114.

—, «Tristán trasquilado a cruces», Cultura Neolatina, LV, 1995, 1-2, pp. 89-99.

—, «La evocación por el olfato», Revista de Filología Románica, Anejo V. Monografías «Los sentidos y sus escrituras», 2007, pp. 47-54. 
—, La caballería de ficción como «educación sentimental», Salamanca, Seminario de estudios medievales y renacentistas, 2010.

RIQUER, Martín de, Los trovadores. Historia literaria y textos, Barcelona, Planeta, 1975 y reimp. Y en la Editorial Ariel.

RonCAglia, Aurelio (1971): «La statua d'Isotta», en Cultura Neolatina, XXXI, pp. 4167.

Tirant lo Blanc, ed. de M. de Riquer, Barcelona, Ariel, 1979.

Tomás de Inglaterra, Berol, María de Francia y otros, Tristán e Iseo. Trad., prólog. y notas de I. de Riquer, Madrid, Siruela, «Biblioteca medieval XIV», 2001.

Tristan et Yseut. Les premières versions européennes. Director Ch. Marchello-Nizia, ediciones y traducciones de R. Boyer, D.Buschinger, A. Crépin, M. Demaules, R. Pérennec, D. Poirion, J. Risset, I. Short, W. Spiewok y H. Voisine-Jechova, París, Éditions Gallimard, «Bibliothèque de La Pléiade», 1995.

Vargas Llosa, Mario, entrevistado por Iker Seisdedos, El País, 29 de septiembre de 2010 . 